\title{
ANALISIS PENGARUH CAPITAL ADEQUACY RATIO TERHADAP RETURN ON ASSET
}

\author{
Rahmawati Maulani ${ }^{1}$, R. Deni Muhammad Danial' ${ }^{2}$, \\ Faizal Mulia $Z^{3}$.
}

\author{
Fakultas Ilmu Administrasi dan Humaniora Universitas Muhammadiyah \\ Sukabumi, Jawa Barat, Indonesia ${ }^{1}$ \\ E-mail : rahmaulani29@gmail.com ${ }^{1}$ \\ Fakultas Ilmu Administrasi dan Humaniora Universitas Muhammadiyah \\ Sukabumi, Jawa Barat, Indonesia ${ }^{2,3}$ \\ E-mail : rdmdanial@gmail.com ${ }^{2}$, paijo_assun@yahoo.com ${ }^{3}$
}

\begin{abstract}
The purpose of this study is to analyze and determine the effect of the Capital Adequacy Ratio on Return On Assets. The subject of this research is one of the banks listed on the Indonesia Stock Exchange, namely. The object of this research is the Capital Adequacy Ratio and Return On Assets. The method used is associative descriptive with a quantitative approach and analyzed using simple linear regression including the test of the coefficient of determination and partial test ( $t$ test). The test results of the determination coefficient test are 0.182 which means that the effect of Capital Adequacy Ratio on Return On Asset is $18.2 \%$, the remaining $81.8 \%$ is influenced by other factors. Based on a simple correlation coefficient test seen from the $R$ value of 0.427 . This shows that the level of the moderate relationship between CAR and ROA. Partially seen from the test $t$ CAR $(X)$ has a significant effect on ROA $(Y)$ with $t$ count of 2.585 and significant at 0.015 .
\end{abstract}

Keywords : capital adequacy ratio; return on asset.

\begin{abstract}
ABSTRAK
Tujuan penelitian ini adalah untuk menganalis serta mengetahui pengaruh Capital Adequacy Ratio terhadap Return On Asset. Subjek penelitian ini adalah salah satu perbankan yang terdaftar pada Bursa Efek Indonesia yaitu . Objek penelitian ini adalah Capital Adequacy Ratio dan Return On Asset. Metode yang digunakan deskriptif asosiatif dengan pendekatan kuantitatif serta di analisis menggunakan regresi linear sederhana termasuk uji koefisien determinasi dan uji parsial (uji t). Hasil penelitian uji koefisien determinasi sebesar 0,182 yang artinya bahwa pengaruh Capital Adequacy Ratio terhadap Return On Asset adalah 18,2\% sisanya 81,8\% dipengaruhi oleh faktor lain. Berdasarkan uji koefisien korelasi sederhana dilihat dari nilai $\mathrm{R}$ sebesar 0,427 . Hal tersebut menunjukan bahwa tingkat hubungan yang sedang antara CAR terhadap ROA. Secara parsial dilihat dari uji t CAR (X) berpengaruh signifikan terhadap ROA(Y) dengan t hitung sebesar 2,585 dan signifikan sebesar 0,015 .
\end{abstract}

Kata kunci : capital adequacy ratio; return on asset. 


\section{PENDAHULUAN}

Perekonomian tidak akan lepas dari peran perbankan terutama di Indonesia. Menurut data Bank Indonesia keseluruhan pertumbuhan perekonomian dari tahun 2015 samjpai 2017 mengalami kenaikan yaitu dari angka 4,79\% di tahun 2015, lalu naik menjadi 5,02\% di tahun 2016 dan sebesar 5,07\% pada tahun 2017 yang menujukkan kinerja yang baik dan positif.

Bank dapat menjadi lembaga intermediasi antara bank itu sendiri dan masyarakat, yaitu menghimpun dana dari masyarakat dalam bentuk simpanan dan disalurkan lagi kepada masyarakat dalam bentuk yang berbeda yaitu kredit. Peranan yang penting dari lembaga perbankan ini membuktikan bahwa perbankan merupakan pondasi utama dalam pembangunan perekonomian Negara dalam menunjang pelaksanaan pembangunan nasional. Seperti yang tertuang di dalam UU No.10 Tahun 1998 Pasal 4 tentang Perbankan yang bertujuan menunjang pelaksanaan pembangunan nasional dalam rangka meningkatkan pemerataan, pertumbuhan ekonomi, dan stabilitas nasional ke arah peningkatan kesejahteraan rakyat banyak.

Bank merupakan sebuah lembaga yang dapat mempertemukan pihak yang memiliki dana lebih dan pihak yang mebutuhkan dana untuk keperluan pribadi maupun kelompok. Pihak yang membutuhkan dana tentu saja tidak akan sembarangan dalam memilih bank untuk dijadikan mitra kerjasama. Mereka akan mempertimbangkan berbagai hal salah satunya kinerja bank tersebut. Bank yang memiliki kinerja yang baik akan memiliki prospek jangka panjang. Indikator yang biasanya digunakan dalam mengukur kinerja bank yaitu profitabiltas. Profitabilitas dapat mengukur kinerja bank dalam memperoleh keuntungan. Kinerja keuangan bank tersebut akan semakin baik apabila profitabilitas yang diperoleh semakin tinggi. Pada umumnya rasio yang digunakan untuk mengukur profitabilitas bank adalah return on asset (ROA) (Yulia, 2015), karena return on asset dapat menunjukkan tingkat efisiensi dalam pengelolaan asset yang dilakukan oleh sebuah bank dan juga dapat menggambarkan kemampuan bank dalam mengelola dana yang telah diinvestasikan dalam keseluruhan aktiva yang dapat memperoleh 
keuntungan. ROA juga dapat memfokuskan dalam kemampuan bank untuk memperoleh keuntungan melalui kegiatan operasi nya.

ROA dapat menggambarkan bagaimana kemampuan bank dalam mengelola aktiva dan produktivitas bank dalam mengelola dana sehingga memperoleh keuntungan. Semakin besar keuntungan yang diperoleh maka akan membuat posisi bank semakin baik sehingga dapat meningkatkan kepercayaan masyarakat untuk menyimpan dana nya pada bank tersebut. Rasio ini sangat berguna bagi nasabah yang ingin mengetahui kinerja bank yang bersangkutan dengan data yang ditampilkan pada laporan keuangan. Salah satu faktor yang mempengaruhi ROA adalah Capital Adequacy Ratio (Soares, 2018). Setiap bank akan selalu terus berusaha untuk meningkatkan modal, karena untuk memenuhi kewajiban menyediakan modal minimum. CAR dapat menujukkan kemampuan bank dalam menyediakan dana untuk keperluan dalam pengembangan usaha dan menutupi resiko kerugian dana yang diakibatkan oleh kegiatan operasi bank tersebut. CAR menujukkan sejauh mana penurunan asset bank yang dapat di tutupi oleh modal yang tersedia. Kemampuan bank dalam meningkatkan modal akan terlihat dari tingginya CAR bank tersebut. Jika nilai CAR cukup maka bank mampu menyerap kerugian pada aktiva berisiko dan dapat membiayai kegiatan operasional yang memberikan kontribusi pada profitabilitas. Dengan tingginya rasio kecukupan modal maka bank dapat melindungi deposan apabila mengalami likuiditas.

Setiap Bank pasti berupaya untuk selalu meningkatkan profitabilitas yang akan diperoleh demi kelancaran dan keberlangsungan hidup Bank tersebut, tidak terkecuali PT Bank Bukopin Tbk. Masalah yang dihadapi oleh PT Bank Bukopin Tbk yaitu nilai profitabilitas yang fluktuatif namun cenderung menurun. Rasio Return On Asset digunakan oleh peneliti untuk mengukur profitabilitas bank. Karena dengan menggunakan ROA, maka dapat dilihat profitabilitas bank yang diukur menggunakan asset yang dana nya dari simpanan masyarakat. Jika ROA bank tinggi maka keuntungan bank tersebut pun akan semakin tinggi.

Tema yang diusulkan yaitu analisis pengaruh capital adequacy ratio terhadap return on asset. Tujuan penelitian ini yaitu untuk mengukur dan 
menganalisis pengaruh capital adequacy ratio terhadap retun on asset pada PT Bank Bukopin Tbk.

\section{METODE PENELITIAN}

Penelitian ini dilakukan pada PT Bank Bukopin Tbk. Metode yang digunakan adalah metode penelitian deskriptif asosiatif untuk mengetahui hubungan antara dua variabel atau lebih. Hubungan antar variabel tersebut dirumuskan dalam hipotesis yang akan diuji. Serta menggunakan pendekatan kuantitaif.

Penelitian ini menggunakan data sekunder yang bersumber dari laporan keuangan triwulan dari tahun 2010 - 2017 PT Bank Bukopin Tbk yang terdaftar di Bursa Efek Indonesia melalui (www.idx.co.id) dan melalui web resmi PT Bank Bukopin Tbk (www.bukopin.co.id) yang kemudian dipelajari, diolah dan dianalisis. Laporan keuangan digunakan untuk mengetahui rasio keuangan. Setelah rasio keuangan dihitung lalu dilakukan analisis dan pengujian terhadap rasio keuangan tersebut.

Analisis data dalam penelitian ini menggunakan analisis regresi linear sederhana termasuk uji koefisien determinasi, dan uji secara parsial (uji t) dengan bantuan program SPSS (Statistic Product \& Services Solution) versi 24.

\section{HASIL DAN PEMBAHASAN}

Regresi linear sederhana didasarkan pada pola hubungan fumgsional ataupun kausal satu variabel independen dengan satu variabel dependen (Sugiyono, 2013:261).

Tabel 1.

Hasil Regresi Linear Sederhana

\begin{tabular}{lcccccc}
\hline & \multicolumn{5}{c}{ Standardized } \\
Model & \multicolumn{7}{c}{ Unstandardized Coefficients } & Coefficients & & \\
\cline { 2 - 5 } (Constant) & $\mathrm{B}$ & Std. Error & Beta & t & Sig. \\
\hline CAR & -22.846 & 9.707 & & -2.354 & .025 \\
\hline
\end{tabular}

a. Dependent Variable: ROA 
Dari output regresi linear sederhana tersebut diperoleh persamaan sebagai berikut :

$$
\mathrm{Y}=1,745(\mathrm{X})-22,846
$$

Tabel 2.

Hasil Koefisien Determinasi

\begin{tabular}{lcccc} 
Model & R & R Square & Adjusted R Square & $\begin{array}{c}\text { Std. Error of the } \\
\text { Estimate }\end{array}$ \\
\hline 1 & $.427^{\mathrm{a}}$ & .182 & .155 & 6.20519 \\
\hline
\end{tabular}

a. Predictors: (Constant), CAR

$\mathrm{R}$ Square menjelaskan seberapa besar variasi $\mathrm{Y}$ yang disebabkan oleh $\mathrm{X}$, dari hasil pengolahan data diperoleh nilai $\mathrm{R}^{2}$ sebesar 0,182 atau $18,2 \%$, artinya $18,2 \%$ tingkat profitabilitas dipengaruhi oleh variabel CAR. Sedangkan sisanya sebesar $81,8 \%$ merupakan pengaruh dari faktor lain.

Tabel 3.

\section{Hasil Koefisien Korelasi}

\begin{tabular}{llccc}
\hline & & & \\
& & & \\
Model & $\mathrm{R}$ & $\mathrm{R}$ Square & Adjusted R Square & $\begin{array}{c}\text { Std. Error of the } \\
\text { Estimate }\end{array}$ \\
\hline 1 & $.427^{\mathrm{a}}$ & .182 & .155 & 6.20519 \\
\hline a. Predictors: (Constant), CAR & & \\
\hline
\end{tabular}

Berdasarkan tabel Model Summary dapat diketahui nilai R adalah 0,427 berada pada kategori 0,40-0,599. Hal tersebut menunjukan bahwa tingkat hubungan yang sedang antara CAR terhadap ROA. 
Tabel 4.

Hasil Uji t

\begin{tabular}{lcrcccc}
\hline & \multicolumn{2}{c}{$\begin{array}{c}\text { Unstandardized } \\
\text { Coefficients }\end{array}$} & $\begin{array}{c}\text { Standardized } \\
\text { Coefficients }\end{array}$ & & \\
\cline { 2 - 4 } Model & $\mathrm{B}$ & Std. Error & Beta & $\mathrm{t}$ & Sig. \\
\hline (Constant) & -22.846 & 9.707 & & -2.354 & .025 \\
\hline CAR & 1.745 & .675 & .427 & 2.585 & .015 \\
\hline
\end{tabular}

a. Dependent Variable: ROA

Hasil uji parsial untuk Capital Adequacy Ratio nilai sig. 0,015 < 0,05, sedangkan nilai $\mathrm{t}$ hitung sebesar 2,585 dan $\mathrm{t}$ tabel 2,042. Sesuai dengan kriteria pengujian bahwa jika $\mathrm{t}_{\text {hitung }}>\mathrm{t}$ tabel $(2,585>2,042)$ artinya secara parsial Capital Adequacy Ratio berpengaruh signifikan terhadap Return On Asset. Hasil Uji Hipotesis, H1 : Capital Adequacy Ratio berpengaruh terhadap Return On Asset.

Berdasarkan hasil perhitungan SPSS, nilai t hitung sebesar 2,585 dengan mengambil taraf signifikan $\alpha$ sebesar 5\% maka t tabel sebesar 2,042, sehingga $t$ hitung $>\mathrm{t}$ tabel $(2,585>2,042)$ dan hasil nilai sig. $0,015<0,05$ menunjukkan bahwa variabel Capital Adequacy Ratio (X) berpengaruh terhadap Return On Asset (Y). Koefisien determinasi $\left(\mathrm{R}^{2}\right)$ diperoleh dari variabel Capital Adequacy Ratio yang mempengaruhi Return On Asset sebesar 18,2\% dan sisanya sebesar 81,8\% dipengaruhi oleh faktor lain. Hasil dari pengolahan data ini menunjukkan bahwa adanya implikasi bahwa Capital Adequacy Ratio berperan dalam meningkatkan Return On Asset.

Hasil dari penelitian ini mendukung bahwa semakin tinggi nilai kecukupan modal (CAR) yang dimiliki oleh suatu bank maka bank tersebut semakin kuat dalam menanggung resiko dari aktiva produktif dan dapat mengembangkan kegiatan operasinya. Hal tersebut dapat menjadi kontribusi yang besar bagi bank karena akan meningkatkan profitabilitas. Pada dasarnya modal merupakan faktor penting untuk mengembangkan usaha dan menampung jika ada kerugian. Rasio kecukupan modal berarti jumlah modal yang diperlukan untuk menutupi adanya 
resiko kerugian yang timbul dari penanaman asset yang berisiko (Veithzal, dkk, 2007:209). Sehingga semakin tinggi modal yang dimiliki oleh suatu bank maka akan meningkatkan profitabilitas.

\section{SIMPULAN}

Berdasarkan analisis yang dilakukan, menunjukkan hasil secara parsial Capital Adequacy Ratio berpengaruh yang signifikan terhadap Return On Aset yang artinya semakin tinggi nilai CAR maka bank akan semakin kuat dalam menanggung risiko dari aktiva produktif.

\section{REFERENSI}

Dendawijaya, Lukman. 2009. Manajemen Perbankan. Jakarta: Ghalia Indonesia

Edwar, Deden. Y.B. (2016) : Pengaruh CAR dan LDR terhadap Return On Asset. Ecodomica, Vol.IV, No.2, 232 - 241

Hanafi, Mamduh M. dan Abdul Halim, 2014, Analisis Laporan Keuangan., Edisi tujuh., UPP AMP YKPN, Yogyakarta

Hantono. (2017) : Effect Of Capital Adequacy Ratio (CAR), Loan To Deposit Ratio (LDR) And Non Performing Loan (NPL) To Return On Assets (ROA) Listed In Banking In Indonesia Stock Exchange, International Journal of Education and Research, Vol. 5, No. 1, $69-80$.

Kasmir. (2012), Analisis Laporan Keuangan. Jakarta : PT. Raja Grafindo Persada.

Ketut, I.W. (2015) : Analisis CAR, NPL, BOPO, NIM, LDR Dan Pengaruhnya Terhadap Profitabilitas Pada Bank Artha Graha Internasional Tbk, Pamulang, Tangerang Selatan, $74-93$.

Nurhasanah, Rahmalia. (2012) : Pengaruh ROA, ROE dan EPS Terhadap Harga Saham. Jurnal Akuntansi, Fakultas Ekonomi, Universitas Widyatama.

Sugiyono. 2012.Metode Penelitian Bisnis. Bandung : Alfabeta.

Sugiyono. 2016. Metode Peneltian Kuantitatif, Kualitif dan R\&D. Bandung: Alfabeta

Satriyo, E.W. (2013) : Analisis Pengaruh Suku Bunga, Inflasi, CAR, BOPO, NPF Terhadap Profitabilitas Bank Syariah. Diponegoro Journal Of Management. Semarang-Indonesia, V.2. No.2. 1 - 10. 
Soares, Pedro. dkk. (2018). The Effect Of NPL, CAR, LDR, OER And Nim To Banking Return On Asset, United Kingdom, International Journal of Economics, Commerce and Management, Vol VI, Issue 3, 2011 - 2016.

Setyo, A.A. (2018) : Effect Of LDR, NPL AND BOPO On Profitabilities Based On CAR (Case Study on Banking Companies Listed on the Indonesia Stock Exchange Period 2013-2017). Semarang-Indonesia.

Widi, Y.K. (2013) : Faktor - Faktor Yang Mempengaruhi Profitabilitas Perbankan Di Indonesia. Diponegoro Journal Of Accounting. Semarang,-Indonesia, 1 12.

Yulia, E.F. (2015) : Pengaruh Rasio Keuangan Dan Variabel Makro Ekonomi Terhadap Kondisi Profitabilitas Bank Muamalat Indonesia Tahun 20042014. $1-16$. 